\title{
EDITORIAL: KOERS VOLUME 81, NO 1, 2016
}

\begin{abstract}
Author:
A Combrink ${ }^{1}$

\section{Affiliation:}

${ }^{1}$ Research associate, Department Languages and Literature, North West University.
\end{abstract}

\section{Correspondence to:}

A Combrink

Email:

annette.combrink@nwu.ac.za

Dates:

15 August 2016

\section{How to cite this article:}

Combrink, A., 2016. "Editorial: KOERS Volume 81, No 1, 2016". KOERS - Bulletin for Christian Scholarship, 81(1). Available at: http://dx.doi.org/10.19108/ koers.81.1.2267

\section{Copyright:}

(C) 2016. The Author(s).

Published under the Creative

Commons Atribution License.
Die tydskrif Koers het sy oorsprong gehad as ' $\mathrm{n}$ Bulletin vir Christelike Wetenskap, en is reeds in sy een-en-tagtigste bestaansjaar. Die tydskrif is inter-dissiplinêr en dus word artikels vanuit alle akademiese velde verwelkom met die voorbehoud dat die artikels ' $\mathrm{n}$ standpuntinname moet bevat wat in beginsel/lewens- en wêreldbeskouing gebaseer is. Waar die sub-titel van die joernaal inderwaarheid "Bulletin vir Christelike Wetenskap" is, is die basis van artikels nog sterk gevestig in 'n Christelike lewens-en wêreldbeskouing maar daar word ruimte gebied vir verskillende beskouings en benaderings tot die werklikheid.

In 'n onlangse brief aan die hoofredakteur word die volgende stelling gemaak: "Ek dink dat Totius en prof. Stoker in hulle graf sou omdraai as hulle sou sien wat van hul Koers geword het - eksplisiet (sic - eksklusief?) engelstalig! Hoekom dan nog die woorde: Koers tydskrif vir chr. wetenskap handhaaf as ' $n$ valse vlag? Ek kan verstaan dat julle die amerikaanse gereformeerdes wil bereik. Maar dis teenswoordig baie maklik om 2-talig te opereer. Eers moet die afr. outeurs hulle afsloof om hulle boodskap in engels korrek te formuleer en daarna moet die afr. leser sukkel om daardie artikel te lees. Mens kan dan 'n 'abstrak' in afr. kry, maar dit is deur 'n masjien vertaal en onverteerbaar à la Google."

Koers is 'n geakkrediteerde tydskrif, en bied dus vir baie akademici 'n baie belangrike publikasiegeleentheid. Die tydskrif word bedryf op die basis van eweknie-evaluering van artikels, en word tans as deel van die "open Source"-metode gepubliseer, wat beteken dat dit wyd beskikbaar is, gelees word, en van groot belang vir akademici, gesiteer word. Dit is dus onvermydelik dat meeste outeurs verkies om in Engels te publiseer, en die keuse van taal word geheel en al oorgelaat aan die outeurs. Afrikaanse bydraes word uiteraard hoog geag en waardeer, en daar is tans ook insentiewe vir Afrikaanstalige artikels. Die opmerking dat dit tans baie maklik is om "tweetalig te opereer" is maklik om te maak - akademiese vertaling is moeilik en duur en kan nie sommer net gedoen word nie. Ook die opmerking oor die kwaliteit van die taal in 'n Afrikaanse abstrak is werklik nie waar nie - alle artikels word professioneel taalversorg, en waar die outeur nie self 'n abstrak in Afrikaans verskaf nie, word dit ook professioneel vertaal.

Maar dat die tydskrif nou hoofsaaklik artikels in Engels publiseer is waar. En dat heelwat artikels gepubliseer word wat nie ' $\mathrm{n}$ eksplisiete Christelike wêreldbeskouing uitstraal nie is ook waar maar die moontlikheid van gesonde en insiggewende debat word hierdeur versterk. Dit is ook interessant dat heelwat artikels uit die veld van opvoedkunde tans vir publikasie aangebied word, en dit dui op die wye belangstelling in opvoedkunde op alle vlakke, wat tans in Suid-Afrika in die brandpunt is.

Dit is miskien ook nodig om outeurs daarop te wys dat in die huidige ekonomiese klimaat akademiese joernale dit baie moeilik vind om te oorleef. Die hele speelveld het ook verander - met die oorskakeling na die Open Journals System is dit nie meer nodig om die koste aan te gaan om baie gedrukte kopieë te publiseer nie (slegs vir outeurs en sekere pligeksemplare aan biblioteke, ens. [en hierdie eksemplare word gratis verskaf) maar die produksie van die joernaal kos nog steeds geld, en meeste joernale oorleef op bladgelde. Hoewel die lede van die redaksie nie salarisse ontvang nie, moet die produksiespan en -proses steeds betaal word, en is daar bepaalde administratiewe kostes.

Hierdie is dus 'n ernstige oproep op outeurs om die fakture aan hulle universiteite/instansies te oorhandig vir betaling. Waar sommige tydskrifte en uitgewers betaling van die bladgelde eis voordat ' $n$ artikel gepubliseer word, wil die Koers-redaksie nie graag daardie paadjie loop nie. Die betaling van bladgelde word nie vereis van buitelandse outeurs nie - Suid-Afrikaanse outeurs het die ondersteuning van hulle instansies om die bladgelde te betaal. 
Ons versoek $\mathrm{u}$ dus vriendelik om $\mathrm{u}$ bladgelde te betaal/ laat betaal. Stuur asseblief bewys van betaling aan support@koers.co.za.

Met vriendelike groete, en dank vir volgehoue ondersteuning aan die joernaal. 'n Joernaal kan ook nie oorleef sonder bydraes van hoë gehalte nie.

Annette Combrink

Hoof Redakteur, Koers

In the Afrikaans foreword to this issue of Koers mention is made of a strongly-worded letter of objection to the fact that the journal has become a largely English-language journal, and the names of Stoker and Totius are invoked in terms of their probable response to what is considered to be an outrage.

The fact that the journal has evolved since the mid-thirties from being an explicit and exclusive Bulletin for Christian scholarship to a more open electronic platform for inter-disciplinary research and engagement, with the requirement for authors to display a stance in terms of their worldview (allowing for justified differences in opinion) has, to my mind, led to scholars increasingly wanting to have a wider audience. Koers is an accredited journal, and therefore an article published in the journal qualifies for subsidy, and also adds to the publications list of an author. It is, therefore, inevitable that English would be the preferred language of publication, although there are still articles submitted in Afrikaans with an English abstract (the remark in the letter, as quoted in the Afrikaans foreword, about the poor quality of Afrikaans translations of abstracts is quite simply not true - abstracts, like articles, are language-edited by professional language practitioners, and not done via Google where the author does not provide an Afrikaans abstract). There are also incentives for academics to publish in Afrikaans. There has been an increase in the number of articles dealing with educational issues, and this is an indication that topical issues are debated in the journal, especially where education is one of the most vexing and worrying issues in South Africa at present.

Koers will continue to publish articles of a high standard, peerreviewed and recommended, and help academics to engage in healthy debate about issues of the day.

It is perhaps also necessary to point out to authors that in the current economic climate academic journals are finding it harder and hard to survive. The whole playing field has changed - with the change to the Open Journals System it is not necessary any more to pay for many hard copies (these are only printed for authors and some compulsory copies for libraries and other repositeries [and these copies are provided free of charge) but the production of the journal still costs money, and most journals only survive on page fees. Although the members of the editorial board do not receive salaries, the production team and process must still be paid, and there are inevitable administrative expenses.

This is therefore an urgent request to authors to submit their invoices to their universities/institutions (where applicable) for payment. Where some journals and publishers demand payment of the page fees before an article is published, the Koers editorial team does not want to follow that route.

We therefore request you cordially to pay your page fees or have them paid. Please send proof of payment to support@koers.co.za.

Yours very sincerely, and thank you for your sustained support of the journal - a journal also cannot survive without quality submissions.

Annette Combrink Editor-in-Chief, Koers 